\title{
FAKTOR SUKU DALAM POLA KOMUNIKASI, PENYESUAIAN SUAMI ISTRI, DAN KEHARMONISAN KELUARGA
}

\author{
Venti Sanditya Septiana ${ }^{1}$, Diah Krisnatuti ${ }^{2}$, Megawati Simanjuntak ${ }^{2^{*}}$ \\ ${ }^{1}$ Kementerian Kesehatan Republik Indonesia, Jakarta 12950, Indonesia \\ ${ }^{2}$ Departemen IImu Keluarga dan Konsumen, Fakultas Ekologi Manusia, Institut Pertanian Bogor, \\ Bogor 16680, Indonesia \\ *E-mail: mega.juntakipb@gmail.com
}

\begin{abstract}
Abstrak
Penelitian ini bertujuan menganalisis pola komunikasi, penyesuaian suami istri, dan keharmonisan keluarga dari suku yang sama dan berbeda. Penelitian ini melibatkan 30 keluarga dari suku yang sama dan 30 keluarga dari suku berbeda yang dipilih secara purposive. Pengumpulan data dilakukan melalui wawancara terhadap suami dan istri dengan bantuan kuesioner. Pola komunikasi diukur dengan cara bagaimana pasangan mengomunikasikan hal-hal yang terjadi di dalam keluarga. Penyesuaian suami istri terdiri dari empat aspek yaitu penyesuaian dengan pasangan, seksual, keuangan, dan keluarga pasangan. Keharmonisan keluarga diukur berdasarkan kepuasan responden. Hasil penelitian menunjukkan bahwa pola komunikasi suami istri pada keluarga sama suku dan beda suku berada pada kategori tinggi. Penyesuaian suami istri dan keharmonisan pada keluarga sama suku dan beda suku berada pada kategori sedang. Penelitian menemukan tidak adanya perbedaan pola komunikasi, penyesuaian, dan keharmonisan keluarga antara keluarga beda suku dan keluarga sama suku $(p>0,05)$. Usia istri, usia menikah dan pendapatan berhubungan signifikan dengan keharmonisan keluarga pada keluarga beda suku. Selain itu, pola komunikasi dan penyesuaian suami istri berhubungan signifikan dengan keharmonisan keluarga pada keluarga sama suku dan beda suku. Secara keseluruhan, pola komunikasi dan penyesuaian suami istri berpengaruh terhadap keharmonisan keluarga.
\end{abstract}

Kata kunci: keharmonisan keluarga, penyesuaian suami istri, perbedaan suku, pola komunikasi

\section{Ethnic Factor in Communication Pattern, Marital Adjustment, and Family Harmony}

\begin{abstract}
The aim of the study was to analyze communication pattern, marital adjustment, and family harmony among two types of ethnic family. This study involved 30 families with husband and wife who were from the same ethnic and 30 families from the different one. The data was collected by interviewing husband and wife and used questionnaires. Communication pattern was measured by how couples communicate each other, while marital adjustment was measured by four aspects that were adjustment with couple, sexual adjustment, financial adjustment, and adjustment to the couple's family. Family harmony was measured by satisfaction level of the respondent. Result showed that communication pattern of both families who were from the same and different ethnic categorized as high while marital adjustment and family harmony were categorized as moderate. There were no differences on communication pattern, marital adjustment, and family harmony between same and different ethnic families $(p>0,05)$. However, wife's age, marriage age, and family income had significant correlation with family harmony in different ethnic families. Additionally, there was a significant positive relationship between communication pattern and marital adjustment with family harmony in both groups of family. In general, factors that affected the family harmony were communication pattern and marital adjustment.
\end{abstract}

Keywords: communication pattern, ethnic, family harmony, marital adjustment

\section{PENDAHULUAN}

Salah satu faktor penting untuk membangun kehidupan keluarga yang kuat adalah terciptanya komunikasi yang baik antara suami dan istri. Komunikasi sangat penting dalam sebuah keluarga, sebagaimana hasil penelitian Muladsih, Muflikhati, dan Herawati (2011) bahwa pola komunikasi dalam keluarga memengaruhi kesejahteraan keluarga. Menurut Eliyani (2013) dan juga Madahi, Samadzadeh, dan Javidi (2013), untuk menjaga suatu hubungan diperlukan adanya komunikasi interpersonal yang terbuka satu sama lain sehingga tercapai hubungan dan kualitas perkawinan. Selain untuk mencapai kebahagiaan pasangan, komunikasi menjadi sarana dalam menyampaikan perasaan bagi pasangan yang berasal dari negara berbeda (Karel, 
Sondakh, \& Pasoreh, 2014). Setelah pasangan dapat saling berkomunikasi maka suami istri dapat saling berbagi dalam sistem interaksi yang selalu berubah dan bergerak maju serta terjadinya perubahan fase kehidupan pada masing-masing pasangan di samping berbagi perasaan, pengasuhan anak-anak, kejadian yang menyenangkan, dan kejadian dalam menghadapi masalah.

Selain itu, tanpa memperhatikan tipe keluarganya, penyesuaian dalam perkawinan merupakan salah satu masalah yang paling sulit dan harus dialami oleh pasangan (Hurlock, 2002). Penyesuaian suami istri dilakukan secara bertahap seiring kehidupan dalam perkawinan dan tahap-tahap ini yang menentukan kebahagiaan pasangan (Anjani \& Suryanto, 2006). Pentingnya penyesuaian dan tanggung jawab sebagai suami atau istri dalam sebuah perkawinan akan berdampak pada keberhasilan dalam hidup berumah tangga. Keberhasilan dalam hidup berumah tangga mempunyai pengaruh yang kuat terhadap adanya kepuasan dalam perkawinan, mencegah kekecewaan, dan perasaan-perasaan bingung, sehingga memudahkan seseorang untuk menyesuaikan diri dalam kedudukannya sebagai suami atau istri serta di kehidupan dalam bermasyarakat (Hurlock, 2002).

Sebuah keluarga dikatakan harmonis jika seluruh anggota keluarga merasa bahagia yang ditandai dengan berkurangnya ketegangan, kekecewaan, dan merasa puas terhadap seluruh keadaan dan keberadaan dirinya yang meliputi aspek fisik, mental, emosi, dan sosial. Nancy (2013) menyebutkan bahwa keharmonisan keluarga berhubungan dengan nilai perkawinan yang mengarahkan persepsi pasangan dan keputusan untuk menghargai, menjunjung tinggi dan mempertahankan perkawinan. Menurut Chuang (2005) memperoleh keharmonisan dan kesejahteraan keluarga diperlukan pola komunikasi yang baik dalam keluarga. Keharmonisan suami istri dalam keluarga menjadi penting karena berdampak pada pelaksanakan peran mereka sebagai orang tua (Sevinc \& Garip, 2010; Alayi, Gatab, \& Khamen, 2011) dan juga berpengaruh terhadap perkembangan anak (Rahayu, Zikra, \& Yusri, 2013). Hurlock (2002) mendefinisikan suami istri yang bahagia yaitu suami istri yang memperoleh kebahagiaan bersama dan menghasilkan keputusan yang diperoleh dari peran yang dimainkan secara bersama, mempunyai cinta yang matang dan mantap satu sama lain, serta dapat melakukan penyesuaian dengan baik. Uraian tersebut menunjukkan bahwa mewujudkan keharmonisan keluarga sangat ditentukan oleh keberhasilan komunikasi dan penyesuaian yang dibangun oleh suami dan istri.

Oleh karenanya, analisis hubungan pola komunikasi dan penyesuaian suami istri dari suku yang sama dan berbeda dikaitkan dengan keharmonisan keluarga perlu dilakukan. Penelitian ini bertujuan untuk mengidentifikasi perbedaan pola komunikasi, penyesuaian antara suami dan istri, dan keharmonisan keluarga sama suku dan beda suku. Penelitian ini juga bertujuan untuk menganalisis hubungan karakteristik keluarga, pola komunikasi, dan penyesuaian suami istri dengan keharmonisan keluarga sama suku dan beda suku. Selain itu, pengaruh karakteristik keluarga, pola komunikasi, dan penyesuaian suami istri terhadap keharmonisan pada keluarga sama dan beda suku juga dianalisis dalam penelitian ini.

\section{METODE}

Penelitian ini menggunakan desain cross sectional. Penelitian ini dilakukan di Komplek Perumahan Bogor Asri, Kelurahan Nanggewer, Kecamatan Cibinong, Kabupaten Bogor, Provinsi Jawa Barat yang dipilih secara sengaja. Alasan yang menjadi pertimbangan adalah perumahan tersebut merupakan daerah dengan latar belakang suku asal penduduk yang heterogen.

Populasi penelitian ini adalah keluarga dengan suami dan istri yang mempunyai latar belakang suku sama dan berbeda di lokasi penelitian terpilih. Teknik penarikan contoh dilakukan secara purposive dengan kriteria suami istri dengan suku yang sama dan berbeda. Jumlah responden adalah 60 pasangan suami istri yang terdiri dari 30 pasangan beda suku dan 30 pasangan sama suku.

Data primer diperoleh melalui wawancara langsung menggunakan alat bantu kuesioner. Data primer yang dikumpulkan meliputi karakteristik suami dan istri (usia, usia ketika menikah, suku, pendidikan, dan pekerjaan), karakteristik keluarga (lama perkawinan, pendapatan keluarga, dan jumlah anggota keluarga), pola komunikasi, penyesuaian suami istri, dan keharmonisan keluarga.

Instrumen yang dikembangkan untuk pengukuran pola komunikasi suami istri didasarkan pada fungsi keluarga menurut BKKBN (1994) yang terdiri dari delapan fungsi 
keluarga. Hal ini untuk memudahkan peneliti dalam membuat pernyataan mengenai pola komunikasi yang dapat mencakup seluruh aspek yang ada di dalam keluarga. Peneliti membuat pernyataan mengenai pola komunikasi berdasarkan fungsi keluarga tersebut, masing-masing fungsi terdiri dari 5 sampai 10 pernyataan, sehingga total dari keseluruhan pernyataan mengenai pola komunikasi ada 51 pernyataan.

Pernyataan mengenai pola komunikasi yang dibuat oleh peneliti ditujukan kepada suami dan istri. Semua pernyataan pada variabel pola komunikasi yang tertuang dalam kuesioner dilakukan skoring (Retnowati, 2007). Skoring yang digunakan dalam penelitian ini dibuat berdasarkan bagaimana cara masingmasing pasangan melakukan komunikasi yaitu verbal, nonverbal, emosional, atau tidak pernah berkomunikasi. Masing-masing jawaban dari pernyataan diberikan skor 1 jika tidak pernah, skor 2 jika emosional, skor 3 jika nonverbal, dan skor 4 jika verbal.

Sementara itu, instrumen pengukuran penyesuaian pasangan dikembangkan peneliti berdasarkan Hurlock (2002) yang membagi ke dalam empat bagian penyesuaian diri pasangan antara lain: penyesuaian dengan pasangan, penyesuaian keuangan, penyesuaian seksual, dan penyesuaian dengan keluarga pasangan. Berdasarkan pembagian tersebut peneliti membuat pernyataan mengenai penyesuaian diri pasangan. Masingmasing bagian terdiri dari 5 hingga 10 pernyataan, sehingga total keseluruhan pernyataan penyesuaian diri pasangan ada $\mathbf{4 0}$ pernyataan.

Pernyataan mengenai penyesuaian diri pasangan yang dibuat oleh peneliti diajukan kepada suami dan istri. Skoring yang digunakan dalam penelitian ini dibuat berdasarkan bagaimana persepsi suami istri terhadap penyesuaian yang dilakukan kepada masingmasing pasangan yaitu apakah sulit, sangat sulit, netral, mudah, dan sangat mudah. Masing-masing pertanyaan diberi skor berdasarkan skala jawaban Likert, yaitu skor 1 jika sangat sulit, skor 2 jika sulit, dan skor 3 jika netral (kadang mudah, kadang sulit), skor 4 jika mudah, skor 5 jika sangat mudah.

Keharmonisan keluarga diukur dengan cara masing-masing pertanyaan diberi skor berdasarkan skala jawaban Likert, yaitu skor 1 jika tidak puas, skor 2 jika kurang puas, skor 3 jika puas, dan skor 4 jika sangat puas.
Selanjutnya, skor yang diperoleh dari masing-masing pertanyaan pada setiap variabel dikompositkan, kemudian dilakukan transformasi skala rasio dari 0-100. Hasil transformasi pada masing-masing variabel tersebut, kemudian dikategorikan ke dalam interval kelas yang dibagi menjadi tiga kelas yaitu rendah $(0-33,3)$, sedang $(33,4-66,6)$, dan tinggi (66,7-100).

Analisis data dilakukan secara deskriptif dan inferensia. Data primer yang dianalisis secara deskriptif terdiri dari karakteristik suami istri dan karakteristik keluarga. Analisis lain yang digunakan adalah uji Korelasi Pearson, uji beda $t$, dan uji regresi linear berganda untuk menjawab tujuan penelitian.

Dalam uji linear berganda yang dibangun dalam penelitian ini terdiri dari tiga model dengan variabel terikat adalah keharmonisan keluarga sama suku, keharmonisan keluarga beda suku, dan keharmonisan seluruh keluarga. Sementara itu, variabel bebas mencakup karakteristik suami istri, karakteristik keluarga, pola komunikasi, dan penyesuaian suami istri.

\section{HASIL}

\section{Karakteristik Suami Istri dan Keluarga}

Hasil penelitian menunjukkan bahwa hampir separuh istri dan suami pada keluarga beda suku, bersuku Jawa masing-masing 43,3 persen dan 33,3 persen, begitu pula pada keluarga sama suku tiga per lima istri dan suami juga bersuku Jawa masing-masing 60,0 persen. Lebih dari tiga per empat istri $(76,7 \%)$ dan lebih dari separuh suami $(53,3 \%)$ pada keluarga beda suku, usianya berada pada kategori 20-40 tahun. Sedangkan pada keluarga sama suku, tiga per lima istri $(60,0 \%)$ usianya berada pada kategori 20-40 tahun dengan rata-rata 38,63 tahun dan lebih dari separuh suami $(56,7 \%)$ usianya berada pada kategori usia 41-60 tahun.

Hampir seluruh istri $(93,3 \%)$ dan lebih dari separuh suami $(73,3 \%)$ pada keluarga beda suku menikah pada rentang usia 20-30 tahun, begitupula pada keluarga sama suku, hampir seluruh istri dan suami masing-masing 96,6 persen dan 83,3 persen, menikah pada kategori usia 20-30 tahun. Pada keluarga beda suku, sepertiga keluarga (33,3\%) lama pernikahannya berada pada kategori 5 hingga 10 tahun dan pada keluarga sama suku, seperempat responden $(26,7 \%)$ lama pernikahannya berada pada kategori 5 hingga 

10 tahun. Hampir sebagian besar suami istri $(80,6 \%)$ pada keluarga beda suku dan lebih dari tiga per lima suami istri $(70,0 \%)$ pada keluarga sama suku termasuk dalam kategori keluarga kecil dengan rata-rata jumlah anggota keluarga empat orang.

Selanjutnya, tingkat pendidikan yang ditempuh suami dan istri pada keluarga sama suku dan beda suku yaitu tamat SMA dan perguruan tinggi. Pekerjaan suami sebagian besar bekerja sebagai pegawai atau karyawan swasta, sedangkan istri tidak bekerja. Sebagian besar pendapatan per kapita per bulan keluarga berkisar lebih dari Rp591.957,00.

\section{Pola Komunikasi}

Hasil penelitian menunjukkan bahwa hampir sebagian besar pola komunikasi pada keluarga beda suku dan sama suku masingmasing 83,3 persen dan 88,3 persen tergolong baik dalam seluruh aspek, yaitu aspek keagamaan, ekonomi, cinta kasih, sosialisasi dan pendidikan, perlindungan, reproduksi, sosial dan budaya, serta pembinaan lingkungan. Sisanya tergolong dalam kategori sedang masing-masing sebesar 16,7 persen dan 11,7 persen. Pada keluarga beda suku, rata-rata aspek pola komunikasi istri paling tinggi berada pada aspek perlindungan $(87,50)$, sedangkan rata-rata pola komunikasi suami paling tinggi berada pada aspek ekonomi $(90,00)$. Pada keluarga sama suku, rata-rata pola komunikasi istri dan suami paling tinggi berada pada aspek ekonomi. Berdasarkan hasil uji beda tidak terdapat perbedaan yang signifikan $(p>0,05)$ antara pola komunikasi suami dan istri pada keluarga beda suku dan sama suku. Nilai rata-rata, standar deviasi, dan koefisien uji beda untuk pola komunikasi pada keluarga beda suku dan sama suku disajikan pada Tabel 1 .

\section{Penyesuaian}

Hasil penelitian menunjukkan bahwa masing-masing kelompok, lebih dari separuh berada pada kategori sedang dalam hal penyesuaian dengan pasangan, penyesuaian seksual, penyesuaian keuangan, dan penyesuaian dengan keluarga pasangan, baik pada keluarga beda suku $(66,7 \%)$ maupun keluarga sama suku (55\%). Sisanya tergolong dalam kategori baik masing-masing 33,3 persen dan 45 persen. Berdasarkan rata-rata aspek penyesuaian pada keluarga beda suku dan sama suku, rata-rata penyesuaian istri dan suami paling tinggi berada pada aspek keuangan. Berdasarkan hasil uji beda, tidak

terdapat perbedaan yang signifikan $(p>0,05)$ antara penyesuaian suami istri pada keluarga beda suku dan sama suku. Nilai rata-rata, standar deviasi, dan koefisien uji beda untuk penyesuaian pada keluarga beda suku dan sama suku disajikan pada Tabel 1.

Tabel 1 Nilai rata-rata, standar deviasi, dan koefisien uji beda untuk pola komunikasi dan penyesuaian pada keluarga beda suku dan sama suku

\begin{tabular}{lccc}
\hline \multirow{2}{*}{ Aspek } & \multicolumn{2}{c}{ Rata-rata \pm standar deviasi } & $p$ - \\
\cline { 2 - 3 } & \multicolumn{2}{c}{ Suami } & \multicolumn{2}{c}{ Istri } & value \\
\cline { 1 - 3 } Pola komunikasi pada keluarga beda suku \\
Keagamaan & $79,1 \pm 23,3$ & $78,2 \pm 30,4$ & 0,820 \\
Ekonomi & $86,9 \pm 21,6$ & $90,0 \pm 16,5$ & 0,580 \\
Cinta kasih & $76,2 \pm 16,4$ & $79,4 \pm 15,8$ & 0,304 \\
Sosialisasi & $84,1 \pm 15,5$ & $88,7 \pm 13,3$ & 0,264 \\
dan & & & \\
pendidikan & & & \\
Perlindungan & $87,5 \pm 12,3$ & $84,6 \pm 15,0$ & 0,798 \\
Reproduksi & $81,3 \pm 23,7$ & $79,3 \pm 21,5$ & 0,967 \\
Sosial dan & $76,2 \pm 25,2$ & $75,1 \pm 25,2$ & 0,527 \\
budaya & & & \\
$\begin{array}{l}\text { Pembinaan } \\
\text { lingkungan }\end{array}$ & $71,6 \pm 26,0$ & $81,8 \pm 20,7$ & 0,519 \\
$\begin{array}{l}\text { Total pola } \\
\text { komunikasi }\end{array}$ & $80,4 \pm 13,9$ & $82,1 \pm 15,6$ & 0,631 \\
\hline
\end{tabular}

\begin{tabular}{|c|c|c|c|}
\hline \multicolumn{4}{|c|}{ Pola komunikasi pada keluarga sama suku } \\
\hline Keagamaan & $79,7 \pm 21,4$ & $81,8 \pm 26,5$ & 0,740 \\
\hline Ekonomi & 8 & & 457 \\
\hline isih & ,7 &, 7 & ,329 \\
\hline $\begin{array}{l}\text { osialisasi } \\
\text { an } \\
\text { endidikan }\end{array}$ & 1 & 1 & 0,051 \\
\hline erlindungan & $90,6 \pm 10,4$ & $85,8 \pm 15,5$ & 0,554 \\
\hline & & & 0,904 \\
\hline 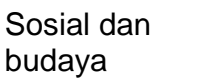 & 78 & & 0,300 \\
\hline & $85,3 \pm 17,7$ & 4 & 0,312 \\
\hline komu & & & \\
\hline \multicolumn{4}{|c|}{ Penyesuaian pada keluarga beda suku } \\
\hline Pasangan & C & & 0,305 \\
\hline & & & 0,719 \\
\hline & & & 253 \\
\hline & $60,1 \pm 16,2$ & & 0,575 \\
\hline Total & $62,7 \pm 10,1$ & $65,1 \pm 11,5$ & 67 \\
\hline \multicolumn{4}{|c|}{ Penyesuaian pada keluarga sama suku } \\
\hline Do & $64,1 \pm 11,2$ & $68,3 \pm 12,0$ & 0,367 \\
\hline & 75 & 1 & 0,694 \\
\hline & 0 & 7 & 0,413 \\
\hline & $61,1 \pm$ & $67,5 \pm 12,4$ & 0,466 \\
\hline $\begin{array}{l}\text { Total } \\
\text { penyesuaia }\end{array}$ & $63,2 \pm 11,7$ & 9 & 0,392 \\
\hline
\end{tabular}





\section{Keharmonisan Keluarga}

Hasil penelitian menunjukkan bahwa, kurang dari dua per tiga keluarga beda suku $(63,3 \%)$ dan dua per tiga keluarga sama suku $(66,7 \%)$ mempunyai keharmonisan keluarga pada kategori sedang, hanya 5,0 persen keharmonisan pada keluarga beda suku dan sama suku yang tergolong kategori baik. Hasil rata-rata indeks keharmonisan keluarga beda suku menunjukkan rata-rata suami lebih tinggi $(43,45)$ daripada istri $(40,52)$, begitupula pada keluarga sama suku, suami juga memiliki ratarata yang lebih tinggi $(46,47)$ dibandingkan istri $(46,23)$. Namun hasil uji beda menunjukkan, baik pada keluarga beda suku maupun sama suku tidak terdapat perbedaan yang signifikan $(p>0,05)$.

\section{Hubungan Antarvariabel}

Hasil penelitian menunjukkan bahwa pada keluarga beda suku terdapat hubungan yang negatif dan signifikan antara usia responden $(r=-0,291, \quad p<0,05)$, usia menikah $(r=-0,287$, $p<0,05)$, dan pendapatan $(r=-0,315, p<0,05)$ dengan keharmonisan keluarga. Hal ini berarti semakin tinggi usia responden, usia menikah, dan pendapatan maka semakin kurang harmonis sebuah keluarga. Selain itu, terdapat hubungan yang positif dan signifikan antara pola komunikasi pada keluarga beda suka $(r=0,405, p<0,05)$ dan keluarga sama suku $(r=0,771, \quad p<0,05)$. Penyesuaian dengan keharmonisan keluarga juga memiliki hubungan yang positif signifikan pada keluarga beda suku $(r=0,423, p<0,05)$ dan pada keluarga sama suku $(r=0,553, p<0,05)$. Hal ini berarti semakin baik pola komunikasi dan penyesuaian, maka semakin harmonis sebuah keluarga (Tabel 2).

Tabel 2 Hubungan karakteristik keluarga, pola komunikasi, dan penyesuaian dengan keharmonisan keluarga

\begin{tabular}{|c|c|c|}
\hline \multirow{2}{*}{ Variabel } & \multicolumn{2}{|c|}{$\begin{array}{c}\text { Keharmonisan } \\
\text { Keluarga }\end{array}$} \\
\hline & $\begin{array}{l}\text { Beda } \\
\text { Suku }\end{array}$ & $\begin{array}{l}\text { Sama } \\
\text { Suku }\end{array}$ \\
\hline Lama pernikahan (tahun) & $-0,166$ & $-0,048$ \\
\hline Usia menikah (tahun) & $-0,287^{*}$ & 0,057 \\
\hline $\begin{array}{l}\text { Besar kelu } \\
\text { arga (orang) }\end{array}$ & $-0,182$ & 0,094 \\
\hline Usia responden (tahun) & $-0,291^{*}$ & 0,006 \\
\hline Lama pendidikan (tahun) & $-0,145$ & 0,062 \\
\hline Pendapatan (Rp) & $-0,315^{\star}$ & 0,065 \\
\hline Pola komunikasi (skor) & $0,405^{\star \star}$ & $0,423^{\star *}$ \\
\hline Penyesuaian (skor) & $0,711^{* *}$ & $0,553^{\star *}$ \\
\hline
\end{tabular}

Keterangan:

* Signifikan pada $p<0,05,{ }^{* *}$ Signifikan pada $p<0,01$
Jika suku tidak dipisahkan, hasil penelitian menunjukkan bahwa terdapat hubungan yang positif dan signifikan antara pola komunikasi istri $(r=0,461, p<0,05)$, pola komunikasi suami $(r=0,458, p<0,05)$, pola komunikasi suami dan istri $(r=0,512, p<0,05)$, penyesuaian istri $(r=-$ $0.690, p<0,05)$, penyesuaian suami $(r=0,562$, $p<0,05)$, penyesuaian suami istri $(r=0,675$, $p<0,05)$, keharmonisan istri $(r=0,899, p<0,05)$, dan keharmonisan suami $(r=0,913, \quad p<0,05)$ dengan keharmonisan keluarga. Hal ini berarti semakin baik pola komunikasi suami istri maka semakin harmonis sebuah keluarga. Penyesuaian suami istri yang semakin baik juga membuat sebuah keluarga semakin harmonis. Selain itu, keharmonisan suami istri yang semakin baik juga membuat sebuah keluarga semakin harmonis. Koefisien korelasi untuk analisis hubungan antara karakteristik keluarga, pola komunikasi suami istri, penyesuaian suami istri, keharmonisan suami istri dengan keharmonisan keluarga disajikan pada Tabel 3.

Tabel 3 Hubungan karakteristik keluarga, pola komunikasi suami istri, penyesuaian suami istri, keharmonisan suami istri dengan keharmonisan keluarga

\begin{tabular}{|c|c|}
\hline Variabel & Keharmonisan Keluarga \\
\hline Lama pernikahan (tahun) & $-0,066^{* *}$ \\
\hline Usia menikah istri (tahun) & $-0,055^{\star *}$ \\
\hline $\begin{array}{l}\text { Usia menikah suami } \\
\text { (tahun) }\end{array}$ & $-0,176^{* *}$ \\
\hline Besar keluarga (orang) & $-0,063^{* *}$ \\
\hline Usia istri (tahun) & $-0,058^{* \star}$ \\
\hline Usia suami (tahun) & $-0,083^{* *}$ \\
\hline $\begin{array}{l}\text { Lama pendidikan istri } \\
\text { (tahun) }\end{array}$ & $-0,016^{* *}$ \\
\hline $\begin{array}{l}\text { Lama pendidikan suami } \\
\text { (tahun) }\end{array}$ & $-0,056^{* *}$ \\
\hline Pendapatan istri (Rp) & $-0,071^{\text {** }}$ \\
\hline Pendapatan suami (Rp) & $-0,047^{* *}$ \\
\hline $\begin{array}{l}\text { Pola komunikasi istri } \\
\text { (skor) }\end{array}$ & $0,461^{* *}$ \\
\hline $\begin{array}{l}\text { Pola komunikasi suami } \\
\text { (skor) }\end{array}$ & $0,458^{* *}$ \\
\hline Penyesuaian istri (skor) & $0,690^{* *}$ \\
\hline $\begin{array}{l}\text { Penyesuaian suami } \\
\text { (skor) }\end{array}$ & $0,562^{* *}$ \\
\hline Keharmonisan istri (skor) & $0,899^{* *}$ \\
\hline $\begin{array}{l}\text { Keharmonisan suami } \\
\text { (skor) }\end{array}$ & $0,913^{* *}$ \\
\hline $\begin{array}{l}\text { Pola komunikasi suami } \\
\text { istri (skor) }\end{array}$ & $0,512^{* *}$ \\
\hline $\begin{array}{l}\text { Penyesuaian suami istri } \\
\text { (skor) }\end{array}$ & $0,675^{\star *}$ \\
\hline
\end{tabular}





\section{Pengaruh Karakteristik Keluarga, Pola Komunikasi, dan Penyesuaian Terhadap Keharmonisan Keluarga}

Model persamaan regresi yang disusun memiliki adjusted $R$ square sebesar 0,329 yang berarti 32,9 persen varian keharmonisan keluarga dapat dijelaskan oleh perubahan dalam variabel-variabel yang ada di dalam model. Variabel yang dimasukkan dalam model adalah lama pernikahan, usia menikah, besar keluarga, usia responden, lama pendidikan, pendapatan, pola komunikasi, dan penyesuaian. Hasil analisis regresi linear berganda menunjukkan bahwa dari delapan variabel yang diduga berpengaruh pada keharmonisan keluarga, hanya ada dua variabel yang berpengaruh signifikan yaitu pola komunikasi $(\beta=0,258, \quad p<0,05)$ dan penyesuaian dengan nilai $(\beta=0,443, p<0,05)$. Pola komunikasi berpengaruh signifikan positif terhadap keharmonisan keluarga sehingga pola komunikasi yang semakin baik dapat meningkatkan keharmonisan keluarga. Keharmonisan keluarga juga meningkat dengan semakin baik-nya penyesuaian suami istri. Koefisien regresi untuk analisis pengaruh karakteristik keluarga, pola komunikasi, dan penyesuaian terhadap keharmonisan keluarga disajikan pada Tabel 4.

Tabel 4 Pengaruh karakteristik keluarga, pola komunikasi, dan penyesuaian terhadap keharmonisan keluarga

\begin{tabular}{|c|c|c|c|}
\hline Variabel & $B$ & $\beta$ & Sig. \\
\hline Konstanta & $-0,138$ & & 0,697 \\
\hline $\begin{array}{l}\text { Suku }(0=\text { beda } \\
\text { suku, } 1=\text { sama } \\
\text { suku) }\end{array}$ & 0,092 & 0,046 & 0,683 \\
\hline $\begin{array}{l}\text { Lama pernikahan } \\
\text { (tahun) }\end{array}$ & $-0,675$ & $-0,675$ & 0,163 \\
\hline $\begin{array}{l}\text { Usia menikah } \\
\text { (tahun) }\end{array}$ & $-0,354$ & -0.354 & 0,203 \\
\hline $\begin{array}{l}\text { Besar keluarga } \\
\text { (orang) }\end{array}$ & $-0,022$ & $-0,022$ & 0,864 \\
\hline $\begin{array}{l}\text { Usia responden } \\
\text { (tahun) }\end{array}$ & 0,486 & 0,486 & 0,286 \\
\hline $\begin{array}{l}\text { Lama pendidikan } \\
\text { (tahun) }\end{array}$ & 0,111 & 0,111 & 0,338 \\
\hline Pendapatan (Rp) & $-0,094$ & $-0,094$ & 0,457 \\
\hline $\begin{array}{l}\text { Pola komunikasi } \\
\text { (indeks) }\end{array}$ & 0,258 & 0,258 & $0,043^{*}$ \\
\hline $\begin{array}{l}\text { Penyesuaian } \\
\text { (indeks) }\end{array}$ & 0,443 & 0,443 & $0,001^{\star *}$ \\
\hline $\mathrm{F}$ & & & 4,212 \\
\hline R Square & & & 0,431 \\
\hline $\begin{array}{l}\text { Adjusted } R \\
\text { Square }\end{array}$ & & & 0,329 \\
\hline
\end{tabular}

\section{PEMBAHASAN}

Setiap sisi kehidupan manusia tidak akan pernah terlepas dari komunikasi. Komunikasi yang baik antara suami dan istri merupakan bagian yang penting dalam kualitas perkawinan (Kammeyer, 1987). Hasil penelitian menunjukkan secara keseluruhan pola komunikasi suami istri tergolong pada kategori baik, baik pada keluarga beda suku maupun sama suku. Menurut Novianti (2013), pola komunikasi dari suku yang berbeda dapat terjalin dengan baik akibat adanya interaksi antar anggota di setiap kegiatan keluarga. Keterbukaan komunikasi suami dan istri menjadi faktor penting sehingga pola komunikasi terjalin dengan baik (Eliyani, 2013).

Penyesuaian suami istri secara keseluruhan tergolong ke dalam kategori sedang, baik pada keluarga beda suku maupun keluarga sama suku. Jika dilihat berdasarkan aspek penyesuaian, pada aspek penyesuaian dengan pasangan, baik istri maupun suami pada keluarga beda suku dan sama suku tidak ada yang berada pada kategori kurang. Hal ini dikarenakan pasangan sudah dapat menyesuaikan diri dengan pasangannya, terkait dengan usia pernikahan pasangan pada keluarga beda suku dan sama suku telah berjalan lebih dari 13, tahun, sehingga pasangan sudah cukup lama mengetahui kelebihan dan kekurangan satu sama lain. Menurut Haber dan Runyon (1984), dalam Hapsariyanti dan Taganing (2009) karakteristik penyesuaian diri yang baik dan harus dimiliki oleh seseorang adalah memiliki persepsi yang akurat terhadap realitas atau kenyataan, mampu mengatasi atau menangani tekanan atau kecemasan, memiliki citra diri yang positif, mampu untuk mengekspresikan perasaan, dan memiliki hubungan interpersonal yang baik. Hal yang lebih penting dalam penyesuaian perkawinan adalah kesanggupan dan kemampuan suami dan istri untuk berhubungan dengan mesra, serta saling memberi dan menerima cinta pasangan (Hurlock, 2002).

Keharmonisan keluarga pada keluarga beda suku dan sama suku secara keseluruhan lebih dari separuhnya berada pada kategori sedang. Hal ini dikarenakan sebagian besar suami istri telah merasa cukup puas dengan apa yang telah dilakukan, hanya sedikit suami istri yang merasa sangat puas terhadap apa yang telah dilakukan untuk keluarga. Berdasarkan hasil uji beda tidak terdapat perbedaan yang signifikan pola komunikasi suami istri, penyesuaian suami istri, dan keharmonisan 

keluarga baik pada keluarga beda suku maupun keluarga sama suku.

Pada keluarga beda suku terdapat hubungan negatif dan signifikan antara usia suami istri, usia ketika menikah, dan pendapatan dengan keharmonisan keluarga. Menurut Gottman \& Notarius (2000) dalam Prasetya (2007) terdapat hubungan negatif antara usia dengan kepuasan perkawinan, meningkatnya usia biasanya disertai dengan kemunduran secara fisik. Kemunduran fisik dapat menimbulkan berbagai persoalan seperti depresi, kemunduran rasa percaya diri dan harga diri. Persoalan-persoalan tersebut akan membuat kepuasan seseorang terhadap perkawinan menjadi semakin berkurang.

Menurut Anjani dan Suryanto (2006) masalah keuangan pun berpengaruh kuat terhadap penyesuaian perkawinan. Berdasarkan hasil penelitiannya beberapa subjek yang diteliti menyatakan bahwa dalam hal keuangan biasanya suami lebih menyerah-kan semua hal keuangan kepada istrinya dan suami merasa kewajibannya hanya mencari uang saja. Banyak suami yang merasa sulit untuk menyesuaikan diri dengan keuangan. Apabila suami tidak mampu menyediakan barangbarang keperluan, maka dapat menimbulkan perasaan tersinggung yang dirasakan oleh istri, dimana perasaan ini dapat berkembang ke arah pertengkaran (Hurlock, 2002). Kesulitan suami istri dalam menyesuaikan diri dengan masalah keuangan akan berdampak pada keharmonisan keluarga.

Pada keluarga beda suku dan sama suku terdapat hubungan positif dan signifikan antara pola komunikasi dan penyesuaian dengan keharmonisan keluarga. Hal ini sejalan dengan hasil penelitian yang menunjukkan komunikasi yang efektif akan mengarah pada kualitas perkawinan yang baik (Lewis \& Spanier, 1979 dalam Kammeyer, 1987). Menurut Hurlock (2002) keberhasilan perkawinan tercermin pada besar kecilnya hubungan interpersonal dan pola perilaku. Komunikasi pada pasangan berbeda suku sangat dibutuhkan terlebih komunikasi antarbudaya yang berfungsi menyatakan identitas sosial, integritas sosial, dan dapat menjadi penghubung antara suami istri agar tercapai kesamaan makna yang diinginkan (Pakpahan, 2013). Ada beberapa kriteria keberhasilan penyesuaian perkawinan antara lain: kebahagiaan suami istri, hubungan yang baik antara anak dan orangtua, penyesuaian yang baik dari anak-anak, kemampuan untuk memperoleh kepuasan dari perbedaan pendapat, kebersamaan, penyesuaian yang baik dalam masalah keluarga, dan penyesuaian yang baik dari pihak keluarga pasangan.

Hasil penelitian ini juga sejalan dengan penelitian yang dilakukan oleh Gottman, Carrere, \& Swanton (1998) dalam Wisnubroto (2009) yang menyatakan adanya hubungan positif antara penyesuaian diri pada pasangan suami istri dengan kebahagiaan perkawinan. Penelitian tersebut dilakukan terhadap 70 pasangan suami istri. Gottman menemukan bahwa pasangan suami istri yang memiliki penyesuaian diri yang tinggi cenderung merasakan kebahagian perkawinan yang tinggi pula. Pasangan suami istri cenderung dapat menghindari perilaku-perilaku yang mengancam keutuhan perkawinannya.

Selain itu, juga terdapat hubungan positif dan signifikan antara pola komunikasi suami, pola komunikasi istri, penyesuaian suami, penyesuaian istri, keharmonisan suami, keharmonisan istri, pola komunikasi suami istri, dan penyesuaian suami istri dengan keharmonisan keluarga. Hal ini berarti semakin baik pola komunikasi dan penyesuaian yang dilakukan oleh suami dan istri, serta semakin harmonis suami dan istri maka akan semakin harmonis sebuah keluarga. Hal ini sejalan dengan hasil penelitian yang dilakukan Dewi \& Sudhana (2013) bahwa keharmonisan sebuah pernikahan tergantung dari kondisi hubungan interpersonal suami istri yang terjalin baik melalui komunikasi interpersonal yang efektif. Komunikasi interpersonal efektif ditunjukkan dengan adanya rasa saling sayang, pengertian, saling menerima, saling menghargai, saling percaya, dan saling mencintai antara suami dan istri.

Adapun faktor yang berpengaruh terhadap keharmonisan keluarga yaitu pola komunikasi dan penyesuaian. Apabila sebuah keluarga memiliki pola komunikasi yang baik dengan anggota keluarganya, terutama komunikasi antara suami dan istri, serta memiliki penyesuaian yang baik maka keharmonisan keluarga akan tercapai. Berdasarkan hasil uji beda tidak terdapat perbedaan yang signifikan antara keharmonisan keluarga pada keluarga beda suku dengan keluarga sama suku. Hal ini berarti keharmonisan sebuah keluarga tidak dilihat dari adanya perbedaan suku maupun kesamaan suku pasangan, melainkan dipengaruhi oleh pola komunikasi dan penyesuaian. Hurlock (2002) menyatakan bahwa pada dasarnya keberhasilan sebuah perkawinan adalah keberhasilan suami istri dalam mewujudkan penyesuaian perkawinan. Jika 

dilihat berdasarkan perbedaan dan kesamaan suku, faktor yang berpengaruh terhadap keharmonisan keluarga pada keluarga beda suku yaitu pendapatan dan penyesuaian. Sedangkan pada keluarga sama suku, faktor yang berpengaruh terhadap keharmonisan keluarga hanya variabel penyesuaian. Hal ini diduga pada keluarga beda suku istri lebih banyak yang tidak bekerja dibandingkan istri pada keluarga sama suku, sehingga pendapatan pada keluarga beda suku berpengaruh terhadap keharmonisan keluarga.

\section{SIMPULAN DAN SARAN}

Secara keseluruhan pola komunikasi suami istri termasuk pada kategori baik, baik pada keluarga beda suku maupun sama suku. Berdasarkan aspek pola komunikasi, pola komunikasi istri maupun suami termasuk pada kategori kurang dalam hal keagamaan, ekonomi, cinta kasih, sosialisasi dan pendidikan, perlindungan, reproduksi, sosial dan budaya, serta pembinaan lingkungan. Penyesuaian responden dan keharmonisan keluarga secara keseluruhan tergolong ke dalam kategori sedang dalam hal penyesuaian dengan pasangan, penyesuaian seksual, penyesuaian keuangan, dan penyesuaian dengan keluarga pasangan, baik pada keluarga beda suku maupun keluarga sama suku. Tidak terdapat perbedaan pola komunikasi, penyesuaian suami istri, dan keharmonisan keluarga pada keluarga beda suku dan sama suku. Hasil uji hubungan pada keluarga beda suku menunjukkan bahwa semakin muda usia dan usia ketika menikah suami istri, serta semakin rendah pendapatan per kapita per bulan maka keharmonisan keluarga semakin tidak puas. Sedangkan pada keluarga sama suku menunjukkan bahwa semakin baik pola komunikasi dan penyesuaian suami istri maka keharmonisan keluarga semakin puas.

Adapun faktor yang berpengaruh terhadap keharmonisan keluarga adalah pola komunikasi dan penyesuaian. Peningkatan pola komunikasi dan penyesuaian menyebabkan peningkatan keharmonisan keluarga. Pada keluarga berbeda suku peningkatan pendapatan dan penyesuaian menyebabkan peningkatan keharmonisan keluarga. Sedangkan pada keluarga sama suku hanya peningkatan penyesuaian yang menyebabkan keharmonisan keluarga semakin baik. Keharmonisan sebuah keluarga ternyata dipengaruhi oleh pola komunikasi dan penyesuaian yang dilakukan oleh suami istri bukan dilihat adanya perbedaan ataupun kesamaan suku. Sebaiknya pasangan suami istri lebih mengembangkan pola komunikasi dengan cara bujukan dan belaian kasih sayang; meningkatkan frekuensi komunikasi satu sama lain; meluangkan waktu untuk melakukan kegiatan bersama; melakukan komunikasi secara terbuka satu sama lain; dan berempati pada pasangan. Selain itu pasangan sebaiknya menambah pengetahuan mengenai cara komunikasi yang baik antara suami istri, baik melalui buku-buku bacaan maupun melakukan konsultasi dengan ahlinya; menyelesaikan konflik secara bersama; melakukan teknik komunikasi yang baik dengan cara mengedepankan empati, keterbukaan, dan teknik menyelesaikan konflik; serta menerima dan memahami kekurangan dan kelebihan diri sendiri dan pasangan agar tidak terjadi konflik antara suami dan istri sehingga keharmonisan keluarga dapat tercapai.

\section{DAFTAR PUSTAKA}

Anjani, C., \& Suryanto. (2006). Pola penyesuaian perkawinan pada periode awal. Jurnal Insan, 8, 198-210.

Alayi, Z., Gatab, T. A., \& Khamen, A. B. Z. (2011). The relationship between parents' marital adjustment, parents' rearing style and health of children in Azad University. Procedia. Social and Behavioral Sciences, 30, 1969-1975.

Chuang, Y. C. (2005). Effects of interaction pattern on family harmony and well being: test of interpersonal theory, relational models theory, and confusion ethnics. Asian Journal of Social Psychology, 8, 272-291.

Dewi, N. R., \& Sudhana, H. (2013). Hubungan antara komunikasi interpersonal pasangan suami istri dengan keharmonisan dalam pernikahan. Jurnal Psikologi Udayana, 1(1), 22-31.

Eliyani, E. R. (2013) Keterbukaan komunikasi pasangan suami istri yang berjauhan tempat tinggal. Ejournal IImu Komunikasi, 1(2), 85-94.

Hapsariyanti, D., \& Taganing, N. M. (2009). Kecerdasan emosional dan penyesuaian diri dalam perkawinan. Jurnal Psikologi, 2, 134-142.

Hurlock, E. B. (2002). Psikologi perkembangan 5h edition. Jakarta, ID: Erlangga.

Kammeyer, K. C. W. (1987). Marriage and Familly: A Foundation for Personal Decisions. Allyn and Bacon, Inc. 

Karel, R. S., Sondakh, M., \& Pasoreh, Y. (2014). Komunikasi antarpribadi pada pasangan suami istri beda negara. Journal Acta Diurna, 3(4).

Madahi, M. E., Samadzadeh, M., \& Javidi, N. (2013). The communication pattern and satisfaction in married student. Procedia. Social and Behavioral Science, 84, 405410.

Muladsih, O. R., Muflikhati, I., \& Herawati, T. (2011). Pola komunikasi, pengambilan keputusan, dan kesejahteraan keluarga jarak jauh: kasus pada keluarga mahasiswa pascasarjana. Jur. IIm. Kel. \& Kons., 4(2), 121-129.

Nancy, M. N. (2013). Hubungan nilai dalam perkawinan dan pemaafan dengan keharmonisan keluarga. Proceeding PESAT (psikologi, ekonomi, sastra, arsitektur dan teknik sipil), 5. ISSN 18582559.

Novianti, E. (2013). Family communication in mixed-marriage between Sundanese and Minangkabau. The International Journal of Social Sciences, 18(1).
Pakpahan, F. B. (2013). Fungsi komunikasi antarbudaya dalam prosesi pernikahan adat batak di Kota Samarinda. E-Journal IImu Komunikasi, 1(3), 234-248. Diambil dari http://ejournal.ilkom.fisip-unmul.ac.id. [diunduh 20 Okt 2011].

Prasetya, B. E. A. (2007). Usia kronologis dan usia pernikahan sebagai prediktor kepuasan pernikahan pada kaum istri di Metro Manila. Jurnal Psikologi Indonesia, 22, 101-107.

Rahayu, K. S. I., Zikra., \& Yusri. (2013). Hubungan antara keharmonisan keluarga dan motivasi belajar siswa. Jurnal IImiah Konseling, 2(1), 191-196.

Sevinc, M. \& Garip, E. S. (2010). A study of parent's child rising styles and marital harmony. Procedia. Social and Behavioral Science, 2, 1648-1653.

Wisnubroto, A. P. (2009). Hubungan antara penyesuaian diri pada pasangan suami istri dengan kebahagiaan perkawinan. Diambil dari http://www.scribd.com/ doc/14094717. [diunduh 20 Okt 2011]. 